Program każdej sesji uzupełniała dyskusja, w której podnoszono kwestie budzące szczególne zainteresowanie lub wątpliwości. Na zakończenie konferencji ks. prof. P. Stanisz dokonał jej podsumowania, wyrażając przekonanie o stałej aktualności nauczania św. Jana Pawła II dla współczesnego Kościoła. Podziękował prelegentom i uczestnikom za wzięcie udziału w obradach. Wyraził także słowa wdzięczności wobec swoich współpracowników z Katedry Prawa Wyznaniowego KUL za zaangażowanie w organizację konferencji.

mgr lic. Konrad Dyda Wydziat Prawa, Prawa Kanonicznego i Administracji Katolicki Uniwersytet Lubelski Jana Pawła II

\title{
Międzynarodowa konferencja naukowa pt. Religion, Cooperation, and Conflict in Diverse Societies, Lozanna (Szwajcaria), 4-7 lipca 2017 r.
}

W dniach 4-7 lipca 2017 roku w Szwajcarii odbyła się 34. Międzynarodowa Konferencja Naukowa pt. Religion, Cooperation, and Conflict in Diverse Societies zorganizowana przez ISSR (International Society for the Sociology of Religion - Międzynarodowe Towarzystwo Socjologów Religii) we współpracy z Uniwersytetem w Lozannie.

Konferencja rozpoczęła się od uroczystego zebrania członków ISSR w dniu 4 lipca 2017 roku. Obrady konferencji zostały podzielone na pięć sesji plenarnych (głównych) oraz na dziesięć sesji tematycznych. Pierwsza sesja tematyczna, w ramach której zostało równolegle wygłoszonych 50 referatów skupiona była na takich zagadnieniach jak: Religiosity: Analysis of International and national Quantitative Surveys; Conversion and Socio-Political Commitment; Religion and non-Religion Across Generations; Religious and Cultural Syncretism, Interpenetration, Fundamentalism, Intolerance and Conflict in Brazil, France and Elsewhere; Culturel, Indigenous Contemporary Religiosities: Between Solidarity, Contestation, Convergence and Renewal; Media and Religion in East Asia; Governing Religious Diversity and Conflict in the City; Global Pentecostal Charismatic Christianities; Judaism, Judaicities. Mutations and Evolutions of the Contempoprary Jewish World; Migration, Religion and Identity; Current 
Concerns in Parish and Congregational Research; Ecology, Religions and Spiritualities: From Socioenvironmental Conflicts to Cosmopolitics; Religion and Education in Contempoprary Plural Societies: A Matter of Neutrality?; Conflicts, Minorities and Interreligious Dialogue; Alternative Sociologies of Religion. Through Non-Western Eyes; Religion in the Public Sphere. The Nordic Countries Since 1980.

Druga sesja tematyczna składała się z 57 referatów wygłoszonych równolegle. Największym zainteresowaniem cieszyły się takie referaty jak: Young Buddhists and the Management of Sexuality and Spirituality: Multiple Stories Andrew Yip (University of Nottingham, UK); Proselytism, Socialisation and New Religious Pratices on the Web: the Exemple of the Raelian Movement Francois Bauduin (EHESS CESOR); How Can We Recognize Religio-Political Movements in Public Sphere? : two Unique Religio-Political Movements and Their Social Impacts in Japan Yoshihide Sakurai (Hokkaido University); Religious Interchange between Japanese Resident in South Korea and Korean Resident in Japan - Focused on the Catholic Church Hyunkyung Lee (Tokai University); Exercising Religion in Prisons - the Case of Croatia Frane Stanicic (University of Zagreb); The Imam, the Muslim Chaplain and the Prison Mallory Schneuwly Purdie (Universite de Lausanne et Centre Suisse islam et societe); Secularization, Desecularization and Religious Toleration Vyacheslav Karpov (Western Michagan University); Jehovah's Witnesses before the European Court of Human Rights: An Impressive Legacy Continues to Build James Richardson (Univeristy of Nevada); Catholic Church and the Public Sphere in Brazil: Controversies about the Rights of Human Embryos and Fetuses in the Brazilian Judiciary Arena Lilian Sales (Universidade Federal de Sao Paulo); It is not Love what Bind us Together: Tensions inside the Argentine Protestantism during the negotiations for a Religious Freedom Act. Pierwszy dzień obrad zakończyła sesja plenarna (szwajcarska). Uroczystego powitania wszystkich uczestników dokonał Jorg Stolz. Następnie wprowadzenia do tematyki sesji plenarnej dokonał Mark Griera. Jako pierwsza głos zabrała Irene Becci na temat 'Grey zones'. Negotiations around religious diversity in Swiss secular institutions. W swoim referacie prelegentka scharakteryzowała sposób postępowania związany z zapewnieniem pluralizmu religijnego w instytucjach państwowych w Szwajcarii. Podała wiele przykładów, w których dochodzi do polubownego załatwienia problemów o charakterze religijnym. Kolejny referat wygłosił Jean-Francois Mayer nt. Pas de minarets au paradis! Le vote suisse du 29 novembre 
2009 et la 'question islamique en Europe. Prelegent przedstawił kontekst podjęcia decyzji o zakazie budowy minaretów w Szwajcarii. Przede wszystkim w referacie przedstawiono argumenty różnych partii politycznych zaangażowanych $\mathrm{w}$ referendum antyislamskie. Jednym z głównych motywów użytych w kampanii przeciwko minaretom było zagrożenie dla tradycji i kultury szwajcarskiej. Ostatni referat wygłosił Christian Joppke pt. Culturalizing Religion in Europe: Patterns and Puzzles. W swoim referacie podkreślił, że w dyskursie politycznym „mulikuturalizm” jest traktowany podejrzliwie z uwagi na to, że nie przyniósł spodziewanych efektów społecznych. W konsekwencji politycy uciekają się do bardziej bezpośredniego i mniej tolerancyjnego podejścia, z najlepszymi intencjami. To jest teraz główny nurt wśród polityków np. w Holandii. Jak stwierdził w konkluzji mniej miękkie podejście daje przynajmniej nadzieję, że będzie bardziej skuteczne.

Następnego dnia (5 lipca 2017 r.) obrady konferencji rozpoczęły się od sesji plenarnej. Wprowadzenia do tematyki dokonała Pani Anna Halafoff. Wykład w sesji plenarnej poprowadziła Lily Kong pt. Mobile bodies, (im) mobile beliefs: religious accord and discord as migratory outcomes. Prelegentka przybliżyła zebranym problem powiązania państwa, religii i edukacji publicznej na przykładzie Hongkongu. Kościoły chrześcijańskie, w tym Kościół Katolicki, utraciły liczne gwarancje prawne wskutek oddania jego terytorium pod administrację Chin. Do 1997 roku nauczanie religii w szkole publicznej było dostępne dla wszystkich uczniów i pozwalało kościołom chrześcijańskim na objęcie kształceniem wszystkich chętnych. Następnie władze Pekinu rozpoczęły proces ujednolicenia kształcenia i wyeliminowania religii ze szkół publicznych. Nowe rozporządzenie szkolne z 8 lipca 2004 roku wprowadziło szereg zmian ograniczających autonomię kościołów w zakresie nauczania religii. Przy wsparciu Kościoła Metodystycznego oraz Anglikańskiego, Diecezja Katolicka Hongkongu zaskarżyła te przepisy. Wyrok pierwszej instancji był niekorzystny dla kościołów chrześcijańskich, stwierdzono w nim m.in. ,organizacje religijne mogą prowadzić szkoły i nauczać religii w szkole, tak jak to miało miejsce przed 1 lipca 1997 r., ale nie oznacza to, że mają one prawo sprzeciwu co do treści programowych publicznego systemu edukacji” (Court of First Instance 2006, HCAL 157/2005). Sprawa trafiła do sądu apelacyjnego, który oddalił apelację, zaś w uzasadnieniu przytoczono następujący argument: ,powinna istnieć równowaga między religijną autonomią a większą przejrzystością zarządzania, bardziej wydajnym zarządzaniem 
i ulepszoną zdolnością do rozliczalności publicznych pieniędzy"(paragraf 68). Sąd nie dopatrzył się w zmianach dotyczących ograniczania nauczania religii w szkole publicznej nielegalnej ingerencji w wolność religijną. Obecnie w Hongkongu zamknięcie szkół wyznaniowych spowodowało przeniesienie praktyk religijnych i nauczania religijnego do życia społecznego, co wpływa na nawiązywanie formalnych i nieformalnych kontaktów między duchownymi, nauczycielami i studentami. Po zakończeniu sesji plenarnej, nastąpiła dyskusja.

Kolejne sesje tematyczne rozpoczęły się po krótkiej przerwie. Wygłoszono na nich łącznie 57 referatów. Największe zainteresowanie wzbudziły takie tematy jak: To Baptize or not to Baptize? Tore Rafoss (KIFO Institute for Church, religion and Worldview Research); Exploring the Intersection of Women's Rights and Human Rights in Religious and Secular Organizations Maia Hallward (Kennesaw State University), Charity Butcher (Kennesaw State University); Religion in Press Discourses about Abortion in Poland Inga Koralewska (Jagiellonian University); Religious Silent Retreat as Rehabilitation Treatment in Swedish Prison Per Pettersson (Uppsala University and Karlstad University); Muslim Chaplaincy in Dutch Prisons: detention and (De)Radicalization Sipco Vellenga (University of Groningen), Kees de Groot (Tilburg University); The Specific and Common Aspects of Religious Culture Education Nobutaka Inoue (Kokugakuin University); The Racialization of Muslims in Switzerland Through Laws Elisa Banfi, Vista Eskandari (University of Geneva), The Pope and the Catholic Church in Italian Media Coverage: Two Different Media Representations Rita Marcheti, Susanna Pagiotti (University of Perugia).

Po przerwie obiadowej nastąpiła czwarta sesja tematyczna, w której zostało wygłoszonych 56 referatów. Do najciekawszych należały: Contemporary Shamanism in Malta: Negotiating Indigenous/Global Relationships Kathryn Rountree (Massey University); Goverening Pluralism in the Urban Space. Religious Communities and Local Political Authorities in Dialogue on the Sacred Places in Rome Valeria Fabretti (Univerisity of Rome Tor Vergata); Catholic Parishes in Australia - a Study in Diversity and Cooperation Bob Dixon (University of Divinity and Australian Catholic University); Secular School and/or Religious Education: A Contemporary Debate in Bulgaria Georgeta Nazarska (State University of Library Studies and IT, Sofia); Is Secular-Lutheran Neutral Enough? Perspectives from the Finnish Context Saila Poulter (University of Helsinki); Religious Communities in Turkey: Between Cooperation and Conflict Mustafa Tekin 
(Istanbul University); Sunnism and Shi'ism: Schism or Harmony? Hossein Godazgar (Al-Maktoum College of Higher Education, Dundee, UK).

Podczas piątej sesji tematycznej zostało wygłoszonych 57 referatów. Największym zainteresowaniem cieszyły się referaty: Adapting religious Beliefs to Secular Context: a Case of Orthodox Community in Russia Ekaterina Grishaeva (Ural Federal University and Uppsala University); Public Policies and Private Believers: The State, the Law and Religion in Canada (Citizenship and Immigration) v. Ishaq [2015] FCA 194 and S.A.S. v. France [2014] ECHR 695 Zaheeda P. Alibhai (University of Ottawa); The Devastating Success of Chaplaincy. Organizing Spiritual Care in a Context of (Hyper) Diversity Kees de Groot (Tilburg University); One to Serve Them All? The Growth of the number of Lutheran Chaplains Increasing in Denmark Lene Kuhle (Aarhus University); Collaboration, Struggle, or Other? Religion and Non-Religion in the Educational Discurse on Biopolitics in Poland Marcin Zwiedrzyński (Jesuit University Ignatianum in Kraków); Religion in Russia Prison: View of Priests and Inmates Elena Medvedeva (Starov State Medical University); Secularization and De-Secularization and the Struggle between the "Religious" and the "Secular" Christiane Konigstedt (University of Leipzig); Religion and State Neutrality in Debates on Assisted Dying in Quebec and the Canton Vaud Samuel Blouin (University of Lousanne/University of Montreal); Religion and Social Conflicts In Nigeria: Boko Haram Insurgency Example Danoye Oguntola-Laguda (Lagos State University); A Dramaturgical Analysis of the Islamic State's Strategies and its Implications for Conceptualizing "Religion” Hadi Sohrabi (Swinburne University/Australia). Wszystkie zaprezentowane referaty spotkały się z ogromnym zainteresowaniem i wywołały burzliwe dyskusje.

W czwartek 6 lipca 2017 roku rozpoczęła się trzecia sesja plenarna, której przewodniczył Francois Gauthier. Wykład wprowadzający wygłosiła Valerie Amiraux pt. Citiziens, piety, and democracy: reflections on the right to secrecy as a condition of political life. W swoim wystąpieniu zwróciła uwagę na konieczność pełnej ochrony życia prywatnego w życiu politycznym. Prelegentka wskazała niebezpieczeństwa, jakie wiążą się z eksponowaniem aspektów życia prywatnego na sferę zachowań społecznych. Dlatego też postulowała, aby zwiększyć ochronę prawną w tej materii. Po referacie nastąpiła ożywiona dyskusja. Wielu dyskutantów wskazało, że postulaty większej ochrony życia prywatnego polityków są praktycznie niemożliwe do zrealizowania w dzisiejszym świecie. 
W trakcie sesji szóstej wygłoszonych zostało 56 referatów. Do najciekawszych zaliczyć można: The Perception of Islamic Gender Inequality in Secularized Western Societies Christel Gartner (Cluster of Excellence Religion and Politics, University of Munster); From Religious to Secular: The afterlife of Closed Churches Jes Heise Rasmussen (University of Copenhagen); Organized Non-Religion/Atheism vs. Religion in Croatia: Where's the Rub? Nikolina Hazdovac Baji (Institut for Social Sciences Ivo Pilar); Religion and Education in Contemporary Plural Societes: a Matter of Neutrality? Stephanie Sannemann-Damstrom (Helsinki University); Explorations of Jewish Religious Culture in a Northern Irish Messianic Congregation. Fieldnotes and Preliminary Analyses Veronique Altglas (Queens University Belfast); Prevention of Radicalization: Religion \& Urbanity in a Swiss city Barbara Heer (University of Basel); Between Selective Acknowledgment and Everyday Harassment: Managing Religious Diversity in Munich Tobias Müller (University of Cambridge); Seductive Atmospheres, Conflicting Symbols: Religious Landmark Buildings in Diverse Societies Silke Steets (TU Berlin); Constructing Conflict: The Politics of Mosque Building Brian Arly Jacobsen (University of Copenhagen); Religious, Social and Commercial Spheres Brought Together Through Built Spaces - the Islamic Diaspora in Converted Buildings Kathrin Herz, Marko Tapio Perels, Chantal Munsch (University of Siegen).

W siódmej sesji tematycznej poruszone zostały następujące zagadnienia, m.in.: Reshaping the Secular in Religious Superdiverse Societes, Religion and Non-Religion Across Generations, Indigenous Contemporary Religiosities: Between Solidarity, Contestation, Convergence and Renewal. Podobnie jak w poprzednich sesjach wygłoszonych zostało blisko 60 referatów, w tym: Religion Makes the Difference! Nonreligious Diversity and its Dependence upon the Religious Context Petra Klug (University of Bremen); Atheists in Argentina: Developing A Nonreligious Identity in a Predominantly Catholic Society Ryan Cragun, J. Sumerau (University of Tampa); No Religion in Brazilian Peripheries: Reflexive Authenticity and Cosmopolitan Ethics Marcos Henrique Nicolini (UMESP-REPAL); Religion Influence in Socio-Environmental Conflicts: a Case Study of the (Limited) Voice of Catholic Church in France Ludovic Bertina (EPHE, Paris Sorbonne); The Greening of Religion Hypothesis' and the Quest for Reliable Survey Research to Assess the Religion-Related Variables that Hinder and Promote Pro-Environmental Behaviors Bron Taylor (University of Florida); Expansion de l'écocentrisme et désinstitutionnalisation 
des religions en Europe Jean-Paul Bozonnet (Science Po Grenoble); The Passion as Ludic Practice. Understanding Public Ritual Performances in Late Modern Society: A Netherlands Case Study Marten van der Meulen (Protestant Theological University, Groningen); Humility and The Gift: The Elective Affinity of Institutions and Ethics in Orthodox Christian Parishes Ivan Zabaev (St.Tikhon's Orthodox University); State Ideology and the Management of Religious Patrimony in Spain and Turkey Avi Astor, Mar Griera (University Autonoma of Barcelona), Marian Burchardt (Max Planck Institute for the Study of Religious and Ethnic Diversity); Irreligion in America: A Justification for a New Normative Framework Hannah Pheasant (Graduate Theological Union); Theodicy of Tsunami: A Study of the Commemorations in Aceh, Indonesia Yu Fukuda, Sébastien Boret (Tohoku University); Le Conseil d'Etat et la laïcité en France: Réflexions autour de deux affaires récentes et emblématiques, celle des «burkini» sur les plages et des crèches de Noël dans les édifices publics" Stéphane Papi (IREMAM - CNRS - AMU); La laïcité de l'entreprise privée: réponse de l'employeur face à l'expression religieuse des employés sur le lieu de travail? Léopold Vanbellingen (Université catholique de Louvain); Dialogue impossible ou nécessaires confrontations inter-convictionnelles à Toulouse (France)? Benoit Petit (Université Jean-Jaurès Toulouse). Po południu tego samego dnia (6 lipca 2017 r.) odbyła się sesja plenarna, której przewodniczył Christophe Monnot. Wykład na temat Secularization, Ethnic Diversity, and Polarization in American Religion wygłosił Mark Chaves. W swoim wystąpieniu zauważył on, iż większość Amerykanów twierdzi, że wierzy w Boga, a ponad jedna trzecia twierdzi, że co tydzień bierze udział w nabożeństwach religijnych. Prelegent odniósł się do aktualnych badań, które pokazują, że ludzie tak naprawdę nie chodzą do kościoła tak często, jak twierdzą, i nie zawsze jest jasne, o co im chodzi, kiedy mówią ankieterom, że wierzą w Boga lub modlą się. Profesor Mark Chaves przedstawił najbardziej aktualne informacje na temat tendencji religijnych w Stanach Zjednoczonych. Według prelegenta zaufanie do instytucji religijnych zmniejszyło się bardziej niż zaufanie do instytucji świeckich, a to powoduje zmiany w postrzeganiu religii w społeczeństwie. Po wykładzie nastąpiła dyskusja, która koncentrowała się wokół problematyki obecności religii w przestrzeni publicznej oraz konieczności dostosowania różnych przejawów religijności w życiu obywatelskim tak, aby nie naruszać pluralizmu. Następnie odbyło się zgromadzenie członków ISSR, na którym debatowano na temat organizacji kolejnej konferencji. 
Po zakończeniu obrad wszyscy uczestnicy udali się na uroczystą kolację na terenie kampusu położonego tuż nad Jeziorem Genewskim. Kolację uświetnił występ kubańskiego zespołu muzycznego Nolosé Music Band.

W piątek 7 lipca 2017 roku obrady rozpoczęły się od sesji ósmej, na której wygłoszono następujące referaty: Sacred Lands: Religious Claims and Environmental Protection Jeronimo Basilio São Mateus (Rovira i Virgili University); The Rise of a Meditating Eco-Militancy? The Pragmatic Turn of Religion and Spirituality in the Swiss French-Speaking Networks Supporting an 'Inner Transition' Approach Alexandre Grandjean (University of Lausanne); Défendre l'environnement pour promouvoir la diversité. Quand des musulmans revendiquent la végétarisation des cantines dans une banlieue parisienne Alexandre Piettre (GSRL-CNRS \& University of Lausanne); Sports, Sex, and God: Evangelical Sports Ministry in the US and the Policing of Sexual Desire Annie Blazer (College of William and Mary); L'homosexualité dans les religions: l'exemple de l'islam Nacer Boukrou (GRHIS - Universite de Rouen); L'Eglise catholique comme dernier placard? Josselin Tricou (Université Paris 8); Religious Pluralism from the Point of View of Religious Collectivities Deirdre Meintel (Université de Montréal); L'escalade des critiques relatives au cours d'Éthique et culture religieuse au Québec: une analyse du marché cognitif Stéphanie Tremblay (Université du Québec à Montréal); Éthique et culture religieuse. Une relecture critique des oppositions Marie-Andrée Roy (Université du Québec à Montréal); Broadening the Horizons of Faith: Media and Religious Tourism Maria Lucia Bastos Alves (Federal University of Rio Grande do Norte-Brazil); Sharing Death. Use of Social Media by the Devotees of Santa Muerte in Mexico Piotr Michalik (Centre for Comparative Studies of Civilisations, Jagiellonian University); The Study of Post-Secularization through the Digital Social: The Undermining of Communicative Action Alphia Possamai-Inesedy (Western Sydney University); Gangology or Theology: what Can Explain Violent Extremism among Muslim Minorities in the West? Mortaza Shams (University of Waikato Islamic Studies Group); Norwegian Muslims on Non-Muslims and Life after Death Levi Geir Eidhamar (University of Agder); The Worldview of Canadian Muslim Millennials on Radicalization, Securitization and Surveillance: Voices of the 9/11 Generation Jasmin Zine (Wilfrid Laurier University); Has Religion Disappeared? Religion and Canada's Highest Legal Institution Cory Steele (University of Ottawa); Religion from, "Private" Belief to "Public" Judgment: Towards a Constructive 
Religious Institutions in the Societies Amany El-Hedeny (Western Sydney University); The Reformation Jubilee 2017 in Denmark from the Perspective of Civil Religion Margit Warburg (University of Copenhagen); Hide and Seek: On Muslim Minorities'Strategies of Engagement/Avoidance in Social-Mediatised Conflict in Scandinavia's 'Bible Belts' and 'Secular Cities' Stefan Fisher-Hoyrem (University of Agder); Trending \#hijabfashion: Using Big Data to Study Religion at the Online-Urban Interface David Herbert (Kingston University); Gender and Mediatization of Religious Diversity Mia Lövheim (Uppsala University); Jewish NGOs and the Promotion of Human Rights Sophie Enos-Attali (Institut catholique de Paris), Elizabeth Sheppard (Université de Tours); Orthodox Christianity, Modernity and the Question of Human Rights Marco Guglielmi (Università degli Studi di Padova); L'instrumentation de la peine de mort en Iran Nader Vahabi (EHESS); Prêtres Fidei Donum belges en Amérique latine: d'une attitude défensive à la théologie de la libération, 1955-1985 Caroline Sappia (Université catholique de Louvain); Tensions and Conflicts in the Pastoral Care of Brazilian Catholics in Japan Antonio Genivaldo Cordeiro de Oliveira (Cordeiro de Oliveira); Expressions of Dialogue among the three Big Christian Branches in Brazil André Ricardo de Souza (UFSCAR Brazil); The Impact of Immigration on Europe's Religious Landscape in 2015 and in the Future Conrad Hackett (Pew Research Center); Religious Pluralisation in Contemporary Europe. Evidence, Revisions and Insights Based on New Estimates on Religious Affiliation Antonius Liedhegener, Anastas Odermatt (University of Lucerne); Religious Affiliation and Religiosity In Poland Wojciech Sadlon (Institute for Catholic Church Statistics); Religiosity Among Millennial Generation in Evangelical Colleges Post-Donald Trump Election in the USA Abolade Olagoke (Waynesburg University); Spirituality and Social Justice Among Canadian Millennials Galen Watts (Queen's University Kingston); In the World of Many. Teaching Islam in Globalized World Wardah Alkatiri (University of Canterbury New Zealand); Protestants United For or By the State? A Case Study in Belgium Jelle Creemers (Evangelische Theologische Faculteit, Leuven); La séparation de l'église et de l'Etat en République tchèque: Comment la nouvelle position en société influence les relations entre le clergé et les laics catholiques? Barbora Spalová (Charles University, Faculty of social sciences, Prague); Routes and Relations between Folk Churches' and Interfaith Initiatives in Scandinavia: Governance, Secularism and the Making of Public Religion Magdalena Nordin (Center for Theology and Religious 
Studies, Lund university, Sweden), Lise Paulsen Galal (Roskilde university), Louise Lund Liebemann (University of Agder); Global Studies and the World Health Organization in the Legitimation of the Ties between Spirituality and Health Rodrigo Toniol (Utrecht University); Pour en finir avec le jugement de Dieu: Antonin Artaud, Anthropologie et la (re)composition du corps Edilson Pereira (UERJ Université d'État de Rio de Janeiro); Sexual Diversity and Popular Religiosity in Mexico: Appropriations from the Subjectivity and the Body Karina Bárcenas Barajas (Institute of Social Research, National Autonomous University of Mexico (UNAM); Do You Want a Funeral by the Church? Church Services as Cultural Residuum after the Secularization in Germany 1982-2002 Heiner Meulemann (University of Cologne); TED Talks on Islam: Post-Secular Digital Media Discourse on Diffused Islam Jasbeer Musthafa Mamalipurath (Institute for Culture and Society, Western Sydney University); The Religion under the Rule of Aesthetics. Some Remarks on the Aestheticization Process of Religion in Brazil (and Elsewhere) Alberto Da Silva Moreira (Pontifical Catholic University of Goias Brazil); Catholic Church and Brazilian Higher Education Institutions Guilherme Arduini (Unicamp); Actions et réactions des jeunes de la classe d'ERE de 11e année autour de la Bible Jorge Triana; Aspects of the School Choice in the Greek-Catholic Educational Institutions in the Focus of Parents's Labor Market Situation, their Qualifications and Social Background Variables Ágnes Inántsy Pap (University of Debrecen).

Po krótkiej przerwie nastąpiła dziewiąta sesja tematyczna, na której wygłoszono następujące referaty: Evangelical Growth and Decline 1970-2013 in Switzerland. Estimations and Explanations Jörg Stolz, Olivier Favre (Université de Lausanne); Theology Matters: The Characteristics of Growing Churches in Korea Sung Gun Kim (Seowon University); Religious Beliefs and Practices National Survey, México 2016 Cristina Gutierrez, Renee De la Torre (University of Guadalajara), Alberto Hernández (El Colegio de la Frontera); Geospatial Pattern of Religious Territorial Units in Serbia Milan Spasojevic (University ok Niš, Serbia); Aperçu des intolérances de jeunes belges musulmans et non-musulmans vis-àvis de l'homosexualité Christine Godesar (UCL /IACCHOS /CISMOC Belgique); Homosexuality in Polish, Catholic Press Discourse - Analysis of Selected two Catholic Magazines Joanna Mleczko (Jagiellonian University); Les femmes salafistes et les effets des Printemps „arabes” en Egypte: from inside to outside Naima Bouras (CEDEJ, Université 
du Havre); L'influence de la religion sur le statut socioéconomique des femmes Mileva Gjurovska (Université de St-Cyrille et Méthode de Skopje, Macédoine); De la femme africaine a la femme chrétienne a travers les nouvelles religiosités au Cameroun Gishleine Oukouomi (Université d'Ottawa); Quand la religion ne comble pas les attentes subjectives (cas des croyants évangéliques au Burkina Faso) Josias Djenne (UBS); Une affaire de famille. Fait religieux populaire et articulation sociale à Séville Hélène Zwingelstein (EHESS); L'expérience des clercs dans la déportation et la résistance, support d'une reconfiguration de l'habitus ecclésial Francois Weiser (GSRL-CNRS); Governing Religious Pluralism with Hegemonies: an Approach to a Catalan Case Vítor Hugo Adami (Universitat Rovira i Virgili); The Governing Religious Diversity and Conflicts in Poland Michał Zawiślak (The John Paul II Catholic University of Lublin); Political Strategies of the Christian Churches to Influence the Process of Secularization. Comparative Study between Mexico City and Liverpool City Felipe Gaytan Alcala (Universidad La Salle, Mexico); Secular and Religious Organisations Offering Austerity Relief Provision: The Interface between Religion in the Public and Private Sphere Elisabeth Arweck (University of Warwick); Programs and Power Struggles. How Does Public Participation Challenge Religious Groups? Ansgar Joedicke (Université de Fribourg); Public, Community Formation and Caste Reconfiguration: A Study of Temples in Kerala, South India Roopesh O B (IIT Bombay); Religious Praxis: Social Positions, Experiences, and Dispositions of Religious Actors Heinrich W. Schäfer (CIRRUS Universität Bielefeld); La nouvelle signification de "l'option pour les pauvres" dans la théologie de la libération Flávio Munhoz Sofiati (Université Fédérale de Goiás); Peace Conceptions, Peace Building Practices and Social Inequality Cecilia A. Delgado-Molina (UNAM, Mexico); Religion, Body and Moral among Children in Brazil's Most Evangelical City Alana Sá Leitão, Roberta Campos (Universidade Federal de Pernambuco (UFPE)); Conservatism, Morality and Evangelicals in Brazil Ronaldo Almeida (Unicamp); Genre, corps et islam. Le travail sur le corps comme projet politique Mari Sol Garcia Somoza; L'écologie spirituelle de Rudolf Steiner: savoirs et imaginaires, pratiques et politiques Aurélie Choné (Université de Strasbourg); Définir les concepts de science et de religion à partir de l'écologie politique Fabrice Flipo (Télécom Ecole de Management); L'écologisme des pauvres et le christianisme de libération dans l'Amérique latine Luis Martinez Andrade; Religion - Space - Communication. Some remarks 
about the Practice of Spacing in Religious Rituals on the Example of Silent Buddhist Meditation Thea D. Boldt (Kulturwissenschaftliches Institut, Essen); Rituels catholiques ubiquitaires en contexte de médias numériques. Réflexion théorique à partir d'un cas ethnographique Olivier Servais (Université catholique de Louvain); Addressing Religion and Politics in Lebanon: New Perspectives on an Old Subject Borja Wladimiro Gonzalez Fernandez (Universidad Autónoma de Madrid); Transdiciplinary Approaches Of The Dialogue Between Science And Religion Alexandra Stavinschi (National Hellenic Research Foundation, Athens); A Foucauldian Analysis of the Discourse on Human Freedom among Muslims in Denmark Johannes Renders (Aarhus University).

Po zakończeniu sesji dziewiątej wszyscy uczestnicy udali się do wyznaczonych miejsc, w których mogli wymienić się wspólnymi doświadczeniami naukowymi, pomysłami dotyczącymi projektów naukowych oraz zapoznać się z aktualnymi rozwiązaniami prawnymi w danych państwach.

Po przerwie nastąpiła ostatnia dziesiąta sesja tematyczna poświęcona takim zagadnieniom jak: Does Religion Explain Political Attitudes? Answers Based on ISSP Surveys in 8 Western European Countries Pierre Bréchon (Institute of Political Studies); Trust Influences Preference for Religious Politicians Peter B. Andersen, Andreas Baumann (University of Copenhagen); Religiosité vs pratique: l'exemple de l'élection présidentielle française de 2017 Claude Dargent (CEVIPOF); The Universal Church of the Kingdom of God in Australia: A Common Sense, Non-Denominational Christian Group Kathleen Openshaw (Religion and Society Research Cluster, Western Sydney University); Brazilian Pentecostal and Charismatic Missions to Europe Paul Freston (Wilfrid Laurier University/Canada/ and UFSCar/Brazil/); Cosmopolitan Pentecostalsm: Hillsong Megachurch Network in Europe Miranda Klaver (Vrije Universiteit Amsterdam); Les enjeux socio-politiques de l'action sociale et humanitaire dans la sphère religieuse: Le profil de l'agence Youth with a Mission en France et au Brésil Denise Goulart (Ecole Pratique des Hautes Etudes/ GSRL); Social Class and Religious Choices in the Filipino Diaspora Astrid Krabbe Trolle (University of Copenhagen).

Dodatkowo należy wspomnieć, że w trakcie każdego dnia obrad odbywały się publiczne recenzje publikacji naukowych. W dniu 4 lipca 2017 r. zrecenzowano książkę James V. Spickard, Alternative Sociologies of Religion. Through Non-Western Eyes, New York: New York University Press, 2017. Recenzentami byli: François Gauthier (Université de 
Fribourg), Mary Jo Neitz (University of Missouri), Peter Beyer (University of Ottawa), Ulrich Berner (University of Bayreuth), Marian Burchardt (Max Planck Institute), Grace Davie (University of Exeter).

Kolejną książką poddaną recenzji była: Inger Furseth (ed.), Religion in the public sphere. The Nordic countries since 1980, New York: Palgrave Macmillan, 2017. W roli recenzentów wystąpili: Michele Dillon (University of New Hampshire), Jörg Stolz (University of Lausanne), Margit Warburg (University of Copenhagen), Lene Kühle (Aarhus University), Mia Lövheim (Uppsala University), Henrik Reintoft Christensen (Aarhus University).

Recenzji została poddana także książka autorstwa Detlef Pollack \& Gergely Rosta, Religion and Modernity: An International Comparison, Oxford University Press: Oxford, 2017. Kolejną monografią poddaną krytyce była Lori G. Beaman, Deep Equality in an Era of Religious Diversity, Oxford: Oxford University Press, 2017. Ponadto następujące pozycje książkowe poddano recenzji w kolejnych dniach konferencji: Hackett, Conrad, David McClendon, Michaela Potancoková, Marcin Stonawski, Caryle Murphy, Vegard Skirbekk. 2016. Religion and Education Around the World. Pew Research Center; S. Lefebvre \& P. Brodeur (eds.), Public Commissions on Cultural and Religious Diversity: Analysis, Reception and Challenges, London: Routledge, 2017; Elisabeth Arweck, Young People's Attitudes to Religious Diversity, London: Routledge, 2017; Heiner Meulemann, Nach der Säkularisierung: Religiosität in Deutschland 1980-2012, Wiesbaden: Springer, 2015; Roberto Cipriani, Diffused Religion. Beyond Secularization, Palgrave Macmillan: London, 2017.

Po zakończeniu obrad, nastąpiła ostatnia piąta sesja plenarna, której przewodniczyła Ingrid Storm. Wykład pt. Divergent Global Roads to Secularization and Religious Pluralism wygłosił José Casanova. Profesor Casanova przywołał teorie sekularyzacji i poddał analizie jedną z nich, która głosi, że religia zniknie z życia społecznego we współczesnych państwach. Jako główny powód takiego stanu rzeczy podał zmieniającą się rzeczywistość technologiczną wypierającą pierwiastek duchowości. Jednocześnie godne podkreślenia jest to, że Europa jest nadal terytorium religijnej homogeniczności i to właśnie powoduje, że przekształci się w świecką homogeniczność, co jest według profesora procesem nieuniknionym. Profesor odniósł się również w swoim wystąpieniu do procesu pluralizmu religijnego, w którym niezbędne będzie wspólne koegzystowanie wielu różnych religii i wierzeń, zapewnione przez rządy poszczególnych państw. 
Po zakończeniu ostatniej sesji plenarnej nastąpiło zebranie Rady ISSR, która podjęła decyzję o powierzeniu organizacji kolejnej konferencji Uniwersytetowi Kardynała Stefana Wyszyńskiego w Warszawie. Ostatniego dnia 8 lipca 2017 roku organizatorzy zapewnili dwie wycieczki dla uczestników konferencji. Pierwsza do Zamku Château de Chillon w Montreux, druga do Muzeum Reformacji w Genewie.

Dr Michał Zawiślak Wydział Prawa, Prawa Kanonicznego i Administracji Katolicki Uniwersytet Lubelski Jana Pawła II

\begin{abstract}
Międzynarodowa konferencja naukowa pt. Status osoby duchownej we wspólczesnym państwie, Bańska Bystrzyca - Badin (Słowacja), 11-13 września 2017 r.
\end{abstract}

W dniach 11-13 września 2017 r. odbyła się międzynarodowa konferencja naukowa pt. Status osoby duchownej we współczesnym państwie, która zorganizowana została przez Polskie Towarzystwo Prawa Wyznaniowego we współpracy z Instytutem Teologicznym im. Św. Franciszka Ksawerego w Bańskiej Bystrzycy - Badinie. Po stronie polskiej koordynatorem wydarzenia był ks. prof. ndzw. dr hab. Piotr Steczkowski z Uniwersytetu Rzeszowskiego. W konferencji wzięło udział kilkadziesiąt osób, wśród których znaleźli się przedstawiciele wielu ośrodków akademickich.

Konferencję otworzył ks. prof. UR dr hab. Piotr Steczkowski oraz prof. UO dr hab. Paweł Sobczyk - Prezes Polskiego Towarzystwa Prawa Wyznaniowego. Moderatorem w 1. sesji był ks. prof. KUL dr hab. Piotr Stanisz. Pierwszy referat wygłoszony został przez dra Mariusza Grabowskiego (UKSW) pt. Prawne aspekty działalności publicznej osób duchownych. Prelegent w swoim wystąpieniu przedstawił problematykę aktywności osób duchownych w życiu publicznym, wskazując liczne przykłady wraz $\mathrm{z}$ oceną prawną poszczególnych problemów prawnych. Kolejny temat Pozycja prawna duchownego w orzecznictwie Europejskiego Trybunału Praw Człowieka przygotował dr Michał Hucał (ChAT), a w zastępstwie tekst odczytała mgr Agnieszka Filak. Treść rozważań obejmowała przede wszystkim analizę dorobku judykatury organów strasburskich. Wyraźnie 